\title{
USING MOTIVATION THEORY TO INFORM ENGINEERING COURSE DESIGN
}

\author{
Monique Sullivan* and Bob Brennan \\ Schulich School of Engineering, University of Calgary \\ msulliva@ucalgary.ca
}

\begin{abstract}
Understanding motivation theory can support engineering educators in effective course design and provide insight into the individual and contrasting motivations of engineering students. This paper explores why there is value for educators to understand motivation theory and how learner orientations influence motivation. A categorization of 2010-2018 CEEA conference proceedings that address student motivation then sets the background for how instructors can use motivation theory to inform course design in lower level technical courses, upper level technical courses, design courses, and assessment.
\end{abstract}

Keywords: Motivation theory: Course design

\section{INTRODUCTION}

In a 2018 survey with engineering faculty across Canada, $53 \%$ of respondents indicated student motivation as one of the top 5 challenges of their work [1]. Additionally, at the 2018 CEEA conference, there were four times as many papers that addressed "student motivation" than the average from 2010 to 2017.

Student motivation, one of the affective elements of student learning, appears to be a relevant and important topic for Canadian engineering educators. One of the challenges, however, is that there is no unified theory of motivation, and many publications that address the topic do not rely on a theoretical framework [2]. Several publications have helped bridge this gap including an approachable framework that can be used as a starting point for engineering education researchers [3], a 2015 systematic review of motivation theory in engineering education research [2], and an exploration of the relationship between motivation theories, achievement, and career plans for engineering students in [4].

This paper explores how motivation theory can support engineering course design. Section two of this paper will briefly explore one framework that captures many of the current theories around student motivation. Section three explores how learner orientations influence motivation. Section four is a brief categorization of CEEA conference proceedings since 2010 that address student motivation.
Section five of this paper explores how motivation theory can be used as a resource for curriculum design.

This paper is not intended to be a thorough overview of motivation theory nor curriculum development, but rather an introduction to the importance, and variability, of their intersection in Canadian engineering classrooms.

\section{IMPORTANCE OF MOTIVATION IN LEARNING}

This paper takes a constructivist view of learning, which states that learning occurs within the learner, is unique to that learner, and depends on what the learner pays attention to [5].

According to [6], motivation is "the process whereby goal directed activities are instigated and sustained." While a student can learn without being motivated, and a motivated student can fail to learn, motivation increases attention, makes a student less distractible, increases persistence (in combination with volition), and supports metacognition [5].

Understanding motivation theory can help identify why a learning intervention may or may not be working, and account for the individual differences between students.

While there is no unifying theory of motivation, there are several frameworks that group them in ways that allow for practical use. The framework chosen for this paper focuses on 4 categories of motivation as defined by Eccles and Wigfield [7], and described in [2]. There are many great resources that expand on these theories including [5]. A very brief summary is provided in Table 1 below. Table 1 also provides examples of questions a student may be asking themselves (consciously or unconsciously), and the connection to curriculum design. The elements of table 1 will be expanded in Section 5 .

Students may engage in a task because they think they will be successful, they believe it will serve them in the future, it matches their values, is inherently interesting, or a combination of many other reasons. Thus motivation is fluid, individual, and multi-dimensional. If motivation is this complex, the question follows: is it possible for educators to design curricula that will motivate entire cohorts of students? 
Table 1: Expectancy theories and relevance to course design.

\begin{tabular}{|c|c|c|c|}
\hline & $\begin{array}{c}\text { Description (adapted from } \\
{[5] \text { ) }}\end{array}$ & $\begin{array}{c}\text { Questions students might } \\
\text { be asking themselves } \\
\text { (adapted from [5]) }\end{array}$ & Relevance to course design \\
\hline $\begin{array}{c}\text { 1. Expectancy } \\
\text { theories }\end{array}$ & $\begin{array}{l}\text { These theories explore a } \\
\text { student's perception of how } \\
\text { difficult a task will be, and } \\
\text { whether or not they expect to } \\
\text { be successful. A common } \\
\text { example is self-efficacy } \\
\text { theory [8], which is } \\
\text { influenced by 1) previous } \\
\text { attempts; 2) watching others; } \\
\text { 3) feedback from peers or } \\
\text { others; and 4) feelings. Note } \\
\text { that the student's actually } \\
\text { abilities are irrelevant here, } \\
\text { only their perceptions of } \\
\text { ability. }\end{array}$ & $\begin{array}{l}\text { - Will this be too hard? } \\
\text { - How likely is it that I will } \\
\text { succeed? } \\
\text { - How did a previous, } \\
\text { similar project go? } \\
\text { - Can I see other students } \\
\text { like me succeeding? } \\
\text { - Does this activity make me } \\
\text { nervous or excited? }\end{array}$ & $\begin{array}{l}\text { Increasing a student's belief } \\
\text { they will be successful may } \\
\text { increase the likelihood they } \\
\text { will engage in the material } \\
\text { and therefore improve } \\
\text { learning outcomes. }\end{array}$ \\
\hline $\begin{array}{c}\text { 2. Theories around } \\
\text { reasons for } \\
\text { engagement }\end{array}$ & $\begin{array}{l}\text { Self-determination theory [9] } \\
\text { focuses entirely on reasons } \\
\text { for engagement, and states } \\
\text { that student motivation lies } \\
\text { on a spectrum from intrinsic } \\
\text { to extrinsic. Increasing } \\
\text { competence, autonomy, and } \\
\text { relatedness help students } \\
\text { move towards intrinsic } \\
\text { motivations, which keep } \\
\text { learning fresh and tend to } \\
\text { improve outcomes. }\end{array}$ & $\begin{array}{l}\text { - How can I show mastery? } \\
\text { - How much control will I } \\
\text { have? } \\
\text { - Will my group be fun to } \\
\text { work with? } \\
\text { - Will my team help me? } \\
\text { - Will I enjoy this? }\end{array}$ & $\begin{array}{l}\text { Helping students understand } \\
\text { how to show mastery, } \\
\text { providing opportunities for } \\
\text { choice, and helping students } \\
\text { feel like they belong to a } \\
\text { community of learners can } \\
\text { help them become more } \\
\text { intrinsically motivated. }\end{array}$ \\
\hline $\begin{array}{c}\text { Theories that } \\
\text { integrate } \\
\text { expectancy and } \\
\text { value }\end{array}$ & $\begin{array}{l}\text { These theories combine a } \\
\text { student's belief they will be } \\
\text { successful with their values. } \\
\text { In Eccles' expectancy value } \\
\text { theory (EVT) there are four } \\
\text { categories of values: 1) } \\
\text { attainment (how success } \\
\text { relates to self-concept); 2) } \\
\text { interest (enjoyment); 3) } \\
\text { utility (future importance); } \\
\text { and 4) relative cost (price in } \\
\text { terms of effort, time, and } \\
\text { psychological impact) [7]. }\end{array}$ & $\begin{array}{l}\text { - What do I get if this goes } \\
\text { well? } \\
\text { - Will this impress others? } \\
\text { - Is this a good way to } \\
\text { develop myself? } \\
\text { - Will this get in the way of } \\
\text { my other goals? } \\
\text { - Do I have enough time? } \\
\text { - Will this increase my } \\
\text { chances of getting a job? }\end{array}$ & $\begin{array}{l}\text { Helping students understand } \\
\text { the value of a learning task, } \\
\text { and adapting tasks so they } \\
\text { more easily relate to student's } \\
\text { values can also improve } \\
\text { motivation. }\end{array}$ \\
\hline $\begin{array}{l}\text { 4. Theories that } \\
\text { integrate } \\
\text { motivation and } \\
\text { cognition }\end{array}$ & $\begin{array}{l}\text { These theories state that self- } \\
\text { regulation behavior requires } \\
\text { motivation. }\end{array}$ & $\begin{array}{l}\text { - How will I fit this into my } \\
\text { day? } \\
\text { - Is this a priority for me? }\end{array}$ & $\begin{array}{l}\text { Increasing motivation can } \\
\text { increase the self-directed } \\
\text { behavior that leads to better } \\
\text { outcomes. }\end{array}$ \\
\hline
\end{tabular}

\section{LEARNER ORIENTATIONS}

One way to increase the likelihood of motivating an entire cohort of students is to acknowledge that students have many different reasons to pursue engineering. They have different expectations, learning needs, and prior knowledge.
This section presents only two orientation frameworks, there are many other ways to further describe learner orientations. The intention here is to emphasize the potentially significant individual differences between students. 


\subsection{Goal Orientation}

If a student's primary goal is to learn, they are considered to have a mastery orientation. Mastery learners are more likely to ask for help, take on big challenges, and learn from mistakes. Ultimately they want to learn, and are less worried about how they look in order to get there [5].

Performance learners however, have a primary goal of doing better than others. They are more likely to use surface learning approaches, avoid mistakes, and choose tasks they know they can accomplish [5]. Their focus is on appearing competent, which can interfere with learning.

Mastery and performance goal orientations are not mutually exclusive, and a student may experience conflicting orientations for the same task. For example, they may truly want to learn something, but are afraid of looking incompetent, and therefore do not ask a necessary question that would improve their learning.

Engineering is a professional degree, and attracts both students who love engineering (mastery orientation) and students who are more focused on wanting to be an engineer (performance orientation). Recognizing the distinction can help educators understand student behaviour.

\subsection{Career Orientation}

The type of career a student is hoping to pursue will also affect their motivation. As noted in [10], engineering graduates group into four non-exclusive career pathways: operations, technological innovation, research, and teaching. While an engineering degree can prepare students for any of these pathways, different skills and attributes are dominant for each. It is important for faculty to remember that the key skills and attributes in their personal career are not the same as those for all engineering pathways.

Additionally, not everyone who completes an engineering degree is interested in pursuing engineering at all [4], as students use engineering as a foundation for careers in law, medicine, and business.

A student's orientation will influence their academic values and priorities, which drive motivation and behaviour. When faculty embrace the diverse ways that students find to make engineering meaningful, they can better understand their student's development processes, and create appropriate learning opportunities [11]. Otherwise, engineering students experience dissonance between their personal understanding of engineering and their education experience, and will struggle to find value in the learning.

\section{CANADIAN LANDSCAPE}

Before looking at how motivation theory can best be used to improve curriculum development, it is important to look at the current Canadian landscape.
A search of the CEEA Conference Proceedings [12] resulted in 50 papers that used the term "student motivation". While the average number of papers using this term from 2010-2017 was only 4, 2018 saw a sharp increase with 16 papers using the term.

Each paper was read and categorized based on the type of course it was referring to, and how it attempted to improve student motivation. One paper was removed as being unrelated.

\subsection{Results of paper categorization (49 total papers)}

The results of the paper categorization are shown in Table 2. Note there is some subjectivity in this categorization, and one paper may fall into more than one category.

The intention of Table 2 is to provide a quick birds-eye view of the discussion around student motivation in the CEEA community.

Table 2: $2010-2018$ CEEA Proceedings with the term "student motivation"

\begin{tabular}{|c|c|c|}
\hline & Topic & CEEA-ACEG Papers \\
\hline \multirow{3}{*}{ 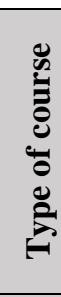 } & Design Courses & 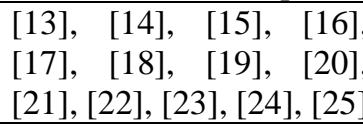 \\
\hline & $\begin{array}{l}\text { Introductory } \\
\text { Technical Courses }\end{array}$ & $\begin{array}{l}{[26],[27],[28],} \\
{[30],} \\
{[31]}\end{array}$ \\
\hline & $\begin{array}{l}\text { Upper Level } \\
\text { Technical Courses }\end{array}$ & {$[32],[33],[34]$} \\
\hline \multirow{5}{*}{ 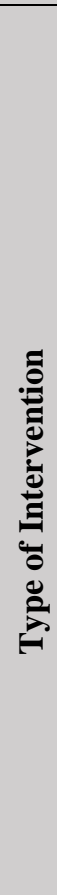 } & $\begin{array}{l}\text { Case Studies, Real- } \\
\text { World Labs, Service } \\
\text { Learning }\end{array}$ & $\begin{array}{l}26],[32], \quad[15], \\
{[28],[34],[31],}\end{array}$ \\
\hline & Course Delivery & $\begin{array}{l}{[26],[27],[29],[36]} \\
{[37],[30],[33],[38],[39}\end{array}$ \\
\hline & Assessment & $\begin{array}{l}{[13],[16],[40],[41]} \\
{[22],[42],[23],[43],[44]}\end{array}$ \\
\hline & $\begin{array}{l}\text { Theory Based or } \\
\text { Survey Results }\end{array}$ & $\begin{array}{l}{[11], \quad[45],[46],} \\
{[10],[19],[48],[1],} \\
{[49],} \\
{[49],[24],[25],} \\
{[51],}\end{array}$ \\
\hline & $\begin{array}{l}\text { Out-of-class } \\
\text { activities }\end{array}$ & 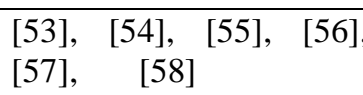 \\
\hline
\end{tabular}


While there have been many successful interventions that improved student motivation discussed in the CEEA 2010-2018 proceedings, the relevant motivation theory behind each intervention is often missing. Understanding motivation theory may not be necessary to create an effective learning environment, however, it can help understand why an intervention is or is not working, and ensure resources are being used effectively [5]. In the next section, we will explore how each motivation influences different aspects of course design.

\section{INTEGRATING MOTIVATION THEORY AND COURSE DESIGN}

In this section we will look at how the first three categories of motivation theory from Table 1 can support course design. Curriculum development is multi-faceted and complex, and motivation theory can help educators understand how a learning intervention may affect students in different ways.

\subsection{Motivation Theory and Introductory Technical Courses}

There are many factors to consider when designing introductory courses, in particular, that prior knowledge and expectations of incoming students vary greatly. Many engineering students were the top of their class in high school, and may not have been challenged academically, meaning they may have succeeded while relying on poor study strategies. They are often mentally and emotionally unprepared for engineering, which results in high levels of stress and anxiety, and reduced motivation [52].

5.1.1 Expectancy Theory. First year engineering is an important time to establish and support students in developing high self-efficacy for challenging technical problems that require applying knowledge in new ways. Many incoming students have beliefs that problem solving should be fast, and if they can't solve problems quickly, they don't understand, or will never understand [59].

First year engineering is a critical time to show students that not knowing an answer right away is ok, sitting and trying to reason through a problem without a solution manual is worth the effort, and not understanding a concept right away does not mean they will be unable to understand.

Appreciating this represents a shift in beliefs for many engineering students who are accustomed to understanding things quickly, and getting near-perfect grades, will enable educators to support them to build the confidence to sit with hard problems, which will have recursive benefits throughout their degree.

This fine balance can be achieved when educators ensure students are exposed to challenging problems right away, and then scaffold the learning experience. Providing multiple forms of assessment, ipsative feedback [16], credit for attempting a harder problem even if the solution is not correct, and providing examples of peers who first struggled and ultimately found success, can all support students in building self-efficacy for engineering problem solving.

Incoming students also have a wide range of prior knowledge. Understanding that a first year student may be struggling because of something outside of their control such as limited resources at their high school, can help to support students who may struggle initially but have strong potential. I.e. if a student had poor exposure to calculus in high school, and struggle in the first few weeks, they may deem themselves unfit for engineering, when the reality is they have just as much potential, and are simply less prepared than their peers.

5.1.2 Reasons for Engagement. The curriculum for first year at most Canadian engineering schools is prescribed by the institution, which means students have low autonomy in course selection. For institutions with a common core first year, students may feel even less autonomy. In [45], teachers reflected that it was difficult to motivate $1 \mathrm{st}$ and 2nd year students in these mandated courses. Providing students with flexibility, such as multiple methods of assessment or choice of project, can help increase student autonomy within mandated courses. For additional information on increasing variety and choice of learning tasks, see [60].

Students who are new to engineering are trying to fit-in with their peers, therefore cultivating relatedness through communities of practice is very important. Engineering culture is generally very good at cultivating communities of practice through extracurricular opportunities, but examining if minority groups are able to find healthy communities of practice at each institution is critical.

Keeping courses novel, and making sure to present the more interesting areas of a subject can improve intrinsic motivation in lower level technical courses. It was found in [26] that by introducing some harder but more interesting concepts in a first year course, they were able to better motivate students.

Real world labs were frequently reflected in CEEA proceedings to increase intrinsic motivation.

Flipped learning can improve autonomy, competence, and interest. Autonomy is increased because students can control when they watch the videos, at what speed, and which ones. Competence is increased because students can review material several times without having to ask a question in front of the whole class. Interest is impacted because students can choose which material is more interesting to them and invest more time as desired. By using flipped learning, the authors of [14] were able to introduce more technical concepts earlier in the course, which allowed time for a more interesting design project at the end of the course. 
A successful example of improving the interest and intrinsic value for a course for all students is outlined in [26], where they successfully implemented open ended design projects to an introductory circuits course. A significant reshuffling of the course was required, where lectures were decreased from 3 to 2 hours per week, and lab time was doubled.

5.1.3. Integration of expectancy and value. First year students often lack time, which means that activities that take a long time and do not count for a large part of an assessment - even when students are intrinsically motivated - may have too high of a relative cost to attempt. If an activity with high cost is being prescribed (either time, mental energy, or stress), it is important to help students understand the value of the task

Incoming students will have differing views on what is means to be an engineer. Attainment theory states that if a learning task matches a student's perceptions of what engineering is, they are more likely to engage [11]. This means providing examples that relate to all possible career goals, or various disciplines (for example in an introductory circuits course, the instructor could explain how electrical engineering relates to civil and chemical engineering).

It has been found that if a task aligns with a student's sense of self (attainment value), they are more likely to persist [2]. For some situations, it may be important to shift the curriculum to meet the students' values. However, incoming students typically have a limited understanding of what engineering is, or what it means to be an engineer [11]. Perhaps there are situations where student values are misplaced and are not supporting their learning, in which case, it may be more important to support students in expanding their understand of themselves as engineers. For example, a student may perceive good grades as the marker of a good engineering student, and therefore use study strategies such as solution manuals to learn patterns and perform well on exams. However, if a student believes strong problem solving to be the marker of a good engineering student, and understands how solution manuals can inhibit that development, they may be less keen to partake.

Providing opportunities for first year students to pursue projects that are intrinsically motivated can improve overall engineering motivation; however, the perceived attainment and utility value of grades conflicts and often overpowers intrinsic value. If a student spends their Saturday participating in a club or team, it means they are not spending their Saturday studying. Many high achieving students, who hold grades with the highest value, will not feel comfortable making that trade off. Educators can reflect on whether they are creating engineering cultures that reinforce the utility value of grades, or if there is space for students to explore the interest value of a self-directed project.
Since value based constructs are individual, opportunities for students to develop metacognition so that they may self-assess and reflect on their learning and goals may be vital to sustaining persistence and motivation through an engineering degree [39], [49], [61] [11]

\subsection{Motivation Theory and Upper Level Technical Courses}

Only three papers addressed student motivation in upper level technical courses. While educators may feel it is not their responsibility to motivate upper year students, their role has shifted to the dual role of supporting student learning in the classroom, and also preparing students to become a practicing professionals [62].

5.2.1 Expectancy. In upper level courses, students will likely have more solidified self-efficacy beliefs based on performance in previous courses. Understanding if a student is not engaging in a course due to low self-efficacy (as opposed to, for example, laziness) can help the instructor better support that student.

Helping students develop increased self-efficacy for self-directed learning will support them when they graduate and also support lifelong learning. This means creating opportunities for students to self-direct their learning, and then reinforcing when it is done well. If opportunities for self-directed learning were not provided in lower level courses, students may feel very uncomfortable with this idea, in which case it is critical to provide the opportunities, and support them through it. This would look like allowing students to design a lab instead of prescribing one, choosing which area of a topic to master, and providing alternative assessments such as an oral exams or a written paper.

5.2.2 Reasons for engagement. Students are preparing to graduate and will be looking for opportunities to be autonomous, in particular if they are returning from internship or co-op. Students may be more particular about which courses they want to master, and which ones they do not see as relevant to their individual goals.

While students often have more autonomy over their courses in upper years, and are thus more intrinsically motivated about the material, if course assessments do not align with learning outcomes, students may revert to surface level learning "in order to pass the course and graduate".

5.2.3 Integration of expectancy and value. Students are preparing to graduate and now have competing demands on their time as they look for work. Their time and attention is split between classroom goals and the immediacy of finding work, which will influence the relative cost of learning activities. 
Helping students see their individual strengths is very powerful in upper year courses, as students are looking for things that will impress future employers, and help them contribute beyond the classroom. Understanding the various orientations of students can help educators create those connections, and help students understand the real world value of their learning (not only the academic or research applications). Describing leaning outcomes in ways that relate to employment opportunities can help students see the value in upper year courses [21]. If course assessment aligns with a student's career goals, they could see double attainment and utility value of the task.

\subsection{Motivation Theory and Design Courses}

5.3.1 Expectancy. Many students choose engineering because they have good math and science scores in high school. Some of these students will not have been exposed to open ended or design problems, and in general, incoming students are not confident in their design skills [46].

The ambiguity of design courses can cause confusion and frustration [46], which may result in low self-efficacy and students who display risk aversion in their design courses. These students may be struggling due to lack of exposure, not inability, and therefore supporting them through this transition with encouragement and low-risk assessment can help bolster self-efficacy.

Helping students manage the discomfort and uncertainty of open ended design projects through coaching and scaffolding, in particular with team composition and task difficulty in their early years will improve self-efficacy beliefs and have a recursive benefit for the rest of their degree [61, 64]. Showing examples of how other students initially struggled and then found success can help boost vicarious learning experiences for students.

Prior knowledge in design elements can vary greatly, with one student having had the opportunity to participate in a robotics club, learn to $3 \mathrm{D}$ print and use Solidworks in high school, and another student having had none of these experiences [21].

Understanding that some students being excited and others anxious within the same design course is not necessarily due to lack of interest or skill. Providing multiple paths for success in these open ended courses can help diverse students engage in the material.

Educators can use capstone design projects to increase student self-efficacy for real-world projects. The flexibility of a capstone can also enable educators to find and emphasize the various unique strengths of each student, and ensure they graduate with strong self-efficacy in workplace related skills.

5.3.2 Reasons for engagement. While it can be easier to increase autonomy in design courses, remember that design could be a new experience for many students.
Students want to feel competent, and if it is not clear how to demonstrate mastery within the course (unclear rubric, or design constraints are unclear), students may be less motivated. Creating specific rubrics for intermediate steps in design allow for better feedback, and provide students with a better understanding of how to prove competency [22].

Keeping the project more open-ended increases the chance for students to choose an intrinsically motivated topic, but if the grading does not match the flexibility, the benefit will be negated.

Design projects are often done in groups, and team dynamics are complex. From the perspective of relatedness, students are trying to fit-in with their group and gain approval from their peers. This could result in some students shying away from sharing their opinion or fully participating.

5.3.3 Integration of expectancy and value. Design projects are often time intensive. It is imperative to help students understand the value of investing that time, and it is critical that assessment align with the goal of the course. For example, do students receive credit for a functional design, or an innovative design that may not be fully functional?

If the design project aligns with the student's perception of engineering, for example, if success in the project makes them feel like an engineer, they are more likely to be motivated to engage.

Design projects require a tolerance for ambiguity and stress, and a need for self-confidence, all which have a high relative cost for students. Integrating these affective factors in formal open-ended problem solving frameworks can encourage students to develop skills to manage them and reduce the relative cost [46].

For capstone design projects, it is essential that students connect the skills developed in the project with skills that will be used in their future career. This could mean expanding the scope of capstone projects to embrace more employment trajectories.

Integrating other courses such as communication into a design course can increase the chance for more students to find value in the project [36].

\subsection{Motivation Theory and Assessments}

Assessments in higher education are tangible and omnipresent. Students rely on them to guide their behaviour, provide feedback, and gauge their progress. However, as explored in Section 3, too much emphasis on assessment can drive students to engage in surface level learning, and avoid risk taking or challenging problems.

5.4.1 Expectancy. While self-efficacy is internal to the student, it can be influenced by their grades, i.e. receiving a good grade in a design course can help support design 
self-efficacy. This is why authentic and aligned assessment is critical to developing engineers with accurate selfefficacy beliefs. For example, if a student has a good grasp of conceptual understanding but the assessments do not provide an appropriate way to demonstrate it, this student may not attempt a related task, because they do not feel they will be successful.

Ipsative assessment, which means measuring student progress, as opposed to assessments which is set against a uniform standard, can support confidence and motivation [16], which support increased self-efficacy.

Pre-assessments help educators understand if a particular learning activity is new for their students. If students have never tried something before, they may have low self-efficacy, and showing students exemplars who have succeeded can help students develop self-efficacy through vicarious experience.

5.4.2 Reasons for engagement. Grades provide both attainment value and utility value, and are therefore the easiest aspect of motivation to control as an instructor. However, grades are external motivators, and a student who was initially intrinsically motivated, may shift orientation in order to complete a task for the grades. Finding the balance of assigning grades and encouraging motivation is not trivial.

5.4.3 Integration of expectancy and value. Students evaluate the cost of spending time on one activity over another. For example, a great assignment that is assigned during exam week may fail to engage students because they lack time, not because it is a poor design [42].

What educators choose to assess within a course validates both those concepts and the correlated behavior.

While summative assessments play a vital role in engineering curricula, there is a need to support selfreflection, self-assessment, and metacognition [49], [61]. Equipping students with these tools allows them to make more accurate value-based assessments, and ensure they are partaking in the tasks most aligned with their future goals. Using multiple assessments simultaneously, such as SPQ (Study process questionnaire), ASI (Approaches to Study Inventory), CMT (Concept Mapping Technique), and ROM (Recursive Object Modeling) can help support the assessment and development of these affective domains [13].

\section{DISCUSSION AND CONCLUSIONS}

Through 9 years of the CEEA conference, many different interventions have been discussed and implemented to improve student motivation, such as flipped learning, integrated courses, case studies, and realworld labs.

While all of these interventions are intended to increase student motivation, ultimately it is the student who must choose to engage and go through the learning process. Understanding motivation theory can help educators develop interventions that support the largest number of students.

Opportunities for students to develop metacognition so they may self-assess and reflect on their individual learning and goals appears to be critical to sustaining persistence and intrinsic motivation through an engineering degree [39], [49], [61].

Educators can collaborate with incoming cohorts to cocreate their vision for engineering, including meaningful challenges, shared values, and identities. Otherwise, students may be left with a sense of dissonance, where their education experience does not match their understanding of engineering [25].

A well-motivated student may still struggle to learn due to a wide variety of factors, including a lack of organization, poor study strategies, poor metacognition, or feeling unsupported. However, finding ways to motivate students can help them persist through challenges, focus on important tasks, and find meaning in their education.

\section{References}

[1] N. Nelson and R. Brennan, "A snapshot of engineering education in Canada," Proc. Can. Eng. Educ. Assoc., Dec. 2018.

[2] P. R. Brown, R. E. McCord, H. M. Matusovich, and R. L. Kajfez, "The use of motivation theory in engineering education research: a systematic review of literature," Eur. J. Eng. Educ., vol. 40, no. 2, pp. 186-205, Mar. 2015.

[3] "A Guidebook On Conceptual Frameworks For Research In Engineering Education."

[4] B. D. Jones, M. C. Paretti, S. F. Hein, and T. W. Knott, "An Analysis of Motivation Constructs with First-Year Engineering Students: Relationships Among Expectancies, Values, Achievement, and Career Plans," J. Eng. Educ., vol. 99, no. 4, pp. 319-336, Oct. 2010.

[5] M. Svinicki, Learning and motivation in the postsecondary classroom. Anker Publishing Company, Inc., 2004.

[6] D. A. Cook and A. R. Artino, "Motivation to learn: an overview of contemporary theories," Med. Educ., vol. 50, no. 10, pp. 997-1014, 2016.

[7] A. Wigfield and J. S. Eccles, "Expectancy-value theory of achievement motivation," Contemp. Educ. Psychol., vol. 25, no. 1, pp. 68-81, 2000.

[8] A. Bandura, "The Explanatory and Predictive Scope of Self-Efficacy Theory," J. Soc. Clin. Psychol., vol. 4, no. 3, pp. 359-373, Sep. 1986.

[9] E. L. Deci and R. M. Ryan, "The What and Why of Goal Pursuits: Human Needs and the SelfDetermination of Behavior," Psychol. Inq., vol. 11, no. 4, pp. 227-268, Oct. 2000. 
[10] J. Hewlett, C. Hoessler, and S. Maw, "Engineering Education: Does Our Training Reflect Student Employment Trajectories ?," Proc. 2015 Can. Eng. Educ. Assoc. Conf., pp. 1-8, 2015.

[11] C. Bennett, M. R. Ha, J. Bennett, and A. Czekanski, "Awareness of the Self and the Engineering Field: Student Motivation, Assessment of 'Fit' and Preparedness for Engineering Education," Proc. Can. Eng. Educ. Assoc., Jan. 2017.

[12] "Proceedings of the Canadian Engineering Education Association (CEEA)."

[13] S. Taheri, R. Gutierrez, Y. Zeng, and C. Marsden, "Effectiveness of Student Learning in an Aerospace Engineering Capstone Project: Investigation of Assessment Methods," Proc. Can. Eng. Educ. Assoc., 2017.

[14] A. D. Spence, D. Ph, and P. Eng, "A CAD Based Concept Car Workflow."

[15] J. Brousseau, A. El Ouafi, and S. Loubert, "Service Learning: A Powerful Appraoch to the Introduction of Engineering Design for Freshman," Proc. Can. Eng. Educ. Assoc., Aug. 2011.

[16] E. Tilley and J. E. Mitchell, "Ipsative learning: a personal approach to a student's experience of PBL within an integrated engineering design cornerstone module," Proc. Can. Eng. Educ. Assoc., Aug. 2015.

[17] D. Effa, S. Lambert, and O. Nespoli, "Learning Engineering Design through Multimedia Case Studies," Proc. Can. Eng. Educ. Assoc., Jun. 2011.

[18] M. Wlodyka and M. Dulat, "Experience with a Small UAV in the Engineering Design Class at Capilano University - A Novel Approach to First Year Engineering Design," Proc. Can. Eng. Educ. Assoc., Aug. 2015.

[19] J.-M. J. Booth, T. E. Doyle, and D. M. Musson, "Influence of Learning Preference on SelfEfficacy and Performance in Mixed-Modality First-Year Engineering Design," Proc. Can. Eng. Educ. Assoc., Jun. 2013.

[20] G. J. Schoenau, "A Final Year Design Course Based on Industry Derived Projects," Proc. Can. Eng. Educ. Assoc., Aug. 2011.

[21] F. Serack, "Student's Perspective on Improvements for Second Year and Other Undergraduate Engineering Design Courses," Proc. Can. Eng. Educ. Assoc., Jun. 2013.

[22] T. F. C. Woodhall and D. S. Strong, "Designing a Rubric to Assess the Modelling Phase of Student Design Projects in Upper Year Engineering Courses," Proc. Can. Eng. Educ. Assoc., Aug. 2011.

[23] R. Carrick and A. Czekanski, "Assessing the Individual in Team Based Design Projects," Proc.
Can. Eng. Educ. Assoc., Dec. 2018.

[24] M. Galaleldin, “The Impact of Student's Academic Locus of Control and Perception of Problem Solving Ability on their Performance in Design Projects," Proc. Can. Eng. Educ. Assoc., Dec. 2018.

[25] M. R. Ha and A. Czekanski, "Meaningful problems in students' design projects: Relational, perceptual, and moral tensions," Proc. Can. Eng. Educ. Assoc., Dec. 2018.

[26] C. Shafai and B. Kordi, "A Laboratory-Centered Approach to Introducing Engineering Students to Electric Circuit and Electric Systems Concepts," pp. 1-6, 2012.

[27] M. Tolman, M. Eggermont, and R. Hugo, "Introduction of Gamification in Common Core Engineering," Proc. Can. Eng. Educ. Assoc., Aug. 2015.

[28] C. Shafai, "Using Broad-Disciplinary Laboratories to Teach Electric Circuits to First Year Students While Introducing Design and Professional Lab Practices," pp. 1-4, 2014.

[29] C. Hulls and C. Rennick, "The Use of a Series of Online Mini-Lectures to Deliver Facts in First Year Programming," Proc. Can. Eng. Educ. Assoc., Jan. 2017.

[30] I. Mattmann, "Increasing System Understanding and Motivation in Students Using Novel Interactive Learning Methods," Proc. Can. Eng. Educ. Assoc., no. Section 2, pp. 3-7, 2017.

[31] R. Al-Hammoud, "Linking Academic Courses with Practical Hands-on Experience for Civil, Environmental and Geological Engineering Students," Proc. Can. Eng. Educ. Assoc., Dec. 2018.

[32] J. S. Deschenes, "Integrating Regional Industrial Theme Examples in Process Control Education," Proc. Can. Eng. Educ. Assoc., Jun. 2012.

[33] G. D. Stubley, "Engineering Elective Course Redesign to Promote Student Engagement," Proc. Can. Eng. Educ. Assoc., Aug. 2015.

[34] H. Wu, S. Omelon, and M. Mujcin, "Use of Cyber Attacks as a Case Study for Design Projects in an Undergraduate Process Control Course," Proc. Can. Eng. Educ. Assoc., Dec. 2018.

[35] S. Lambert, C. Newton, and D. Effa, "Ten Years of Enhancing Engineering Education with Case Studies: Insights, Lessons, and Results from a Design Chair," Proc. Can. Eng. Educ. Assoc., Jan. 2017.

[36] D. M. Douglas, C. R. Johnston, D. J. Caswell, and M. Eggermont, "Writing in the Engineering Design Lab: Integrating Communication Skills into the Engineering Curriculum," Proc. Can. Eng. Educ. Assoc., Aug. 2011.

[37] K. Cook and R. Jacob, "Where Language and 
Engineering Meet: Fostering Emerging Engineering Identities Amoung International English Language Learners," Proc. Can. Eng. Educ. Assoc., Feb. 2018.

[38] J. Pringle and G. Potvin, "The Right Tools for the Job: Discipline-Specific Language-Learning for First-Year International Engineering Students," Proc. Can. Eng. Educ. Assoc., Dec. 2018.

[39] R. Habash, "Unleashing Knowledge Creation and Sharing in a Reflective Open Education," Proc. Can. Eng. Educ. Assoc., Dec. 2018.

[40] B. Frank and D. Strong, "Development of a Design Skill Assessment Tool," Proc. Can. Eng. Educ. Assoc., Jul. 2010.

[41] J. Kaupp, N. Simper, and B. Frank, "Triangulated authentic assessment in the HEQCO Learning Outcomes Assessment Consortium," Proc. Can. Eng. Educ. Assoc., Aug. 2015.

[42] M. Stachowsky and A. J. B. Milne, "What Makes a Good Assessment? Assessments for Learning," Proc. Can. Eng. Educ. Assoc., Dec. 2018.

[43] M. Sullivan and R. Brennan, "Evolution of Canadian Engineering Education Assessment Practice 2010-2017," Proc. Can. Eng. Educ. Assoc., Dec. 2018.

[44] N. Simper, B. Frank, and N. Mulligan, "NetworkBased Approach to Assessment of Cognitive Skills," Proc. Can. Eng. Educ. Assoc., Dec. 2018.

[45] L. Akhmadeeva, M. Hindy, and C. J. Sparrey, "Overcoming Obstacles To Implementing an Outcome-Based Education Model: Traditional Versus Transformational Obe," Proc. Can. Eng. Educ. Assoc., pp. 1-5, 2013.

[46] A. Huynh and S. McCahan, "Undertsanding the Literature on Problem Analysis," Proc. Can. Eng. Educ. Assoc., Aug. 2015.

[47] B. Crowell and P. Gregson, "The Importance of Mental Representations in Design Engineering," Proc. Can. Eng. Educ. Assoc., Aug. 2011.

[48] A. . Deacon, N. Larson, T. A. O’Neill, R. . Brennan, M. Eggermont, and W. Rosehart, "The Self-Directed Learning Readiness Scale, Conscientiousness, and the Prediction of Engineering Student Learning Outcomes," Proc. Can. Eng. Educ. Assoc., Aug. 2015.

[49] G. J. Evans, "Windmills of Your Mind: Metacognition and Lifelong Learning," Proc. Can. Eng. Educ. Assoc., Dec. 2018.

[50] H. Smith and D. Strong, "Creative Confidence and the Arts: Measuring a Potential Contributing Factor to Students' Motivation to Engage in Engineering Creativity," Proc. Can. Eng. Educ. Assoc., Dec. 2018.

[51] C. Rennick and K. McKay, "Componential Theories of Creativity: A Case Study of Teaching Creative Problem Solving," Proc. Can. Eng. Educ.
Assoc., Dec. 2018

[52] E. Kuley, S. Maw, and T. Fonstad, "Understanding Barriers to Student Success: What Students Have to Say," Proc. Can. Eng. Educ. Assoc., Jan. 2017.

[53] M. R. Ha and A. Amirfazli, "Impacting the teaching culture: Role of the department and the software tools," Proc. Can. Eng. Educ. Assoc., Jan. 2017.

[54] I. Ivkovic, T. L. Willett, M. J. Borland, and M. Gorbet, "Design Days Boot Camp: Enhancing Student Motivation to Start Thinking in Engineering Design Terms in the First Year," Proc. Can. Eng. Educ. Assoc., Feb. 2018.

[55] R. O. Buchal, "The Educational Value of Student Design Competitions," Proc. Can. Eng. Educ. Assoc., pp. 1-9, 2004.

[56] M. H. Shehata, "Co-Curricular Activities and their Role in Supporting Experiential Learning," Proc. Can. Eng. Educ. Assoc., Aug. 2015.

[57] B. Walsh and M. Spence, "Leveraging Escape Room Popularity to Provide First-Year Students with an Introduction to Engineering Information," Proc. Can. Eng. Educ. Assoc., Dec. 2018.

[58] M. Klassen and J. Donald, "Using an Academic Plan Model to Analyze Canadian Engineering Leadership Curriculum," Proc. Can. Eng. Educ. Assoc., Dec. 2018.

[59] A. H. Schoenfeld, "Learning to Think Mathematically: Problem Solving, Metacognition, and Sense Making in Mathematics (Reprint)," $J$. Educ., vol. 196, no. 2, pp. 1-38, 2016.

[60] R. M. Felder and R. Brent, "The Intellectual Development of Science and Engineering Students. Part 2: Teaching to Promote Growth," $J$. Eng. Educ., vol. 93, no. 4, pp. 279-291, Oct. 2004.

[61] C. Bennett, M. R. Ha, J. Bennett, and A. Czekanski, "Awareness of Self and the Engineering Field: Student Motivation, Assessment of 'fit' and Preparedness for Engineering Education," Proc. Can. Eng. Educ. Assoc., Jan. 2017.

[62] M. K. Ponton, J. H. Edmister, L. S. Ukeiley, and J. M. Seiner, "Understanding the Role of SelfEfficacy in Engineering Education," J. Eng. Educ., 2001.

[63] A. Huynh and S. McCahan, "Understanding the Literature on Problem Analysis," Proc. Can. Eng. Educ. Assoc., Aug. 2015. 